\title{
ЗОНИРОВАНИЕ ТЕРРИТОРИИ МО Г. ТУЛЫ ПО КАРСТОПРОЯВЛЕНИЮ
}

\section{Ирина Анатольевна Басова}

Тульский государственный университет, 300600, Россия, г. Тула, пр. Ленина, 92, доктор технических наук, зав. кафедрой геоинженерии и кадастра, тел. (4872)73-44-28, e-mail: biajis20051@ya.ru

\section{Виктор Владимирович Чекулаев}

Тульский государственный университет, 300600, Россия, г. Тула, пр. Ленина, 92, кандидат технических наук, доцент кафедры геоинженерии и кадастра, тел. (4872)73-44-28, e-mail: chekulaev@mail.ru

В результате анализа выявлена степень пораженности территории г. Тула карстовыми процессами; на основе изучения литологического состава массива горных пород, тектонической нарушенности и интенисвности проявления на поверхностии предложена карта-схема зонирования территории МО г. Тула по фактору карстообразования.

Ключевые слова: карстово-суффозионные процессы, комплексная оценка городских земель, районирование и зонирование земель по фактору карстонарушенности

\section{ZONING OF THE TERRITORY OF MUNICIPALITY OF TULA BY KARST}

\section{Irina A. Basova}

Tula State University, 92, Lenin Ave., Tula, 300600, Russia, D. Sc., Head of the Department of Geoengineering and Cadastre, phone: (4872)73-44-28, e-mail: biajis20051@ya.ru

\section{Victor V. Chekulaev}

Tula State University, 92, Lenin Ave., Tula, 300600, Russia, Ph. D., Associate Professor, Department of Geoengineering and Cadastre, phone: (4872)73-44-28, e-mail: chekulaev@mail.ru

As a result of the analysis, the degree of damage to the territory of Tula by karst processes is revealed; based on the studying of the lithological composition of the rock mass, tectonic disturbance and intensity of manifestation on the surface, a map-scheme of zoning of the territory of Tula municipality by the karst formation factor is proposed.

Keywords: karst-suffusion processes, integrated assessment of urban land, zoning and zoning of land on the factor karstonarushennosti

На территории Тульской области опасные экзогенные геологические процессы проявляются достаточно широко, зачастую наносят значительный материальный ущерб народному хозяйству, а иногда и создают реальную угрозу безопасности жизнедеятельности человека. Наибольшую опасность представляет карстонарушенность территории. Степень пораженности территорий карстовыми процессами некоторых районов области составляет более 50 \% [2-6, 9, 14, 15].

Известно, что для обеспечения комплексной оценки состояния городских земель необходимо учитывать влияние отдельных природных факторов [10, 
11]. При этом, одним из самых высоких значений весовых коэффициентов показателей, используемых для оценки городских земель, являются карстовосуффозионные процессы (весовой показатель - 0,3) [10,11].

По состоянию на 01.01.2019 Управление Россреестра по Тульской области не располагает актуализированным картографическим материалом, позволяющим судить о состоянии и использовании земель [12]. Для эффективного управления земельными ресурсами, а также для совершенствования оценки состояния, качества и в целях разработки комплекса почвозащитных мероприятий, мероприятий по экономическому стимулированию собственников и пользователей в рациональном использовании и охране земель крайне необходимы пространственно обобщенные, регионально систематизированные и сопоставимые данные о земле. С этой целью в настоящей работе приведены результаты зонирования территории г. Тула по фактору карстонарушенности.

Определяющая роль тектоники и литологии в распространении карста и проявлении его на поверхности дает основание положить их в основу районирования территории по подверженности карстовым процессам.

Районирование проводится в соответствии с принципами, изложенными И.В. Поповым $[7,8]$. Принимается пятиступенчатая схема: регион - область подобласть - район - подрайон - участок. Первые пять единиц таксономического ряда выделяются по условиям развития карста, пятая - участок - по проявлению его на поверхности.

В соответствии со схемой районирования карста Русской равнины Тульская область расположена на территории Московско-Окской и СевероСреднерусской карстовой провинции, которая входит в состав ЦентральноРусской карстовой области. Тульская область расположена на территориях Заокского, Окско-Донского карстовых округов [13].

Территория Большой Тулы относится к Тульскому карстовому району.

В Тульском карстовом районе карст наиболее интенсивно развит на Скуратовском, Липковском, Дедиловском и Рождественском участках.

По литологическому составу карстующихся пород области подразделяются на подобласти. На территории Тульской области поверхностный карст связан с выщелачиванием известняков и доломитов среднего и нижнего карбона, и загипсованных известняков и доломитов заволжского и верхнефаменского возраста. В связи с этим выделяются две подобласти: карбонатного и сульфатно-карбонатного карста. В южной и северной частях Тульской области развит карбонатный карст, в центральной части - сульфатно-карбонатный.

О значении литологического состава и мощности покровных отложений как о факторе, контролирующем проявление карстовых процессов говорилось выше. Они и послужили критерием для выделения районов и подрайонов. Районы выделены по присутствию в перекрывающей толще водоупора или его отсутствию. В районах с отсутствием регионального водоупора выделены подрайоны по суммарной мощности слабопроницаемых пород (суглинков и глин) в перекрывающей толще: менее 20 м и более 20 м. На территории с интенсивным проявлением кар- 
ста на поверхности выделены участки. В случаях, когда площади поверхности характеризуются единичными кротовыми проявлениями, районирование прекращается на уровне подрайона.

На основе анализа распространения карста по Тульской области выделено 13 участков интенсивного карстопроявления [15].

При этом интенсивность проявления карстовых процессов рекомендуется оценивать количеством воронок, приходящихся на единицу территории. Шкала оценки карстовых процессов на городских землях представлена в табл. 1.

Таблица 1

Шкала оценки карстово-суффозионных процессов на городских землях

$[1,10]$

\begin{tabular}{|c|c|}
\hline $\begin{array}{c}\text { Количество воронок, } \\
\text { ед./км }\end{array}$ & Интенсивность проявления процессов \\
\hline нет & Отсутствуют \\
\hline 1 & Слабая \\
\hline $2-5$ & Опасная \\
\hline$>5$ & Чрезвычайная \\
\hline
\end{tabular}

Для детального изучения распространения карста, с точки зрения его влияния на расположение функциональных городских зон, на территории Большой Тулы, в соответствии с литологическим составом карстующихся пород, наиболее целесообразно выделить участки, которые, в свою очередь, по интенсивности проявления процесса на поверхности делятся на более мелкие таксонометрические единицы - подучастки. В качестве критериев такого деления предлагается ввести изученность, плотность и вероятность проявления карстов.

К территории Большой Тулы относятся следующие участки: Рождественский, Центральный и Скуратовский. В пределах Рождественского участка предлагается выделить следующие подучастки: РождественскоХомяковский, Обидимско-Малининский и Хомяково-Архангельский. На территории Центрального участка находятся Щегловский подучасток в низовьях рр. Сежа-Бежка, подучасток в низовьях рр. Бежка-Тулица-Волоть, подучасток Волоть-Упка. К Скуратовскому участку относятся Ливенский и Янополянско-Коптевский подучастки.

На основе изучения геологического строения района его тектонических и гидрогеологических особенностей произведено зонирование проявления процессов карстов (табл. 2).

Полученные результаты могут быть использованы организациями, занимающимися вопросами оценки состояния и качества земельных ресурсов, кадастровой оценки земельных участков, а также специалистами структур- 
ных подразделений, осуществляющих градостроительную, землеустроительную и кадастровую деятельность.

Таблица 2

Краткая характеристика выделенных участков и подучастков

\begin{tabular}{|c|c|c|c|c|c|}
\hline $\begin{array}{l}\text { Назва- } \\
\text { ние } \\
\text { участка }\end{array}$ & $\begin{array}{c}\text { № под- } \\
\text { участ- } \\
\text { ка на } \\
\text { карто- } \\
\text { схема }\end{array}$ & Название подучастка & $\begin{array}{c}\text { Формы проявления } \\
\text { карста }\end{array}$ & $\begin{array}{c}\text { Пло- } \\
\text { щадь } \\
\text { участка } \\
, \text { км }^{2}\end{array}$ & $\begin{array}{c}\text { Средняя } \\
\text { плотность } \\
\text { карстопро- } \\
\text { явлений, } \\
\text { шт/км² }\end{array}$ \\
\hline \multirow[t]{3}{*}{$\begin{array}{l}\text { Рожде- } \\
\text { ствен- } \\
\text { ский }\end{array}$} & 1 & $\begin{array}{l}\text { Рождественско- } \\
\text { Хомяковский }\end{array}$ & $\begin{array}{c}\text { Воронки, карстовые } \\
\text { котловины, поноры, } \\
\text { слепые овраги }\end{array}$ & 258,7 & Более 5 \\
\hline & 2 & $\begin{array}{l}\text { Обидимско- } \\
\text { Малининский }\end{array}$ & Воронки & 47,55 & 3 \\
\hline & 3 & $\begin{array}{c}\text { Хомяково- } \\
\text { Архангельский }\end{array}$ & Воронки & 114,1 & 3 \\
\hline \multirow[t]{5}{*}{$\begin{array}{c}\text { Цен- } \\
\text { траль- } \\
\text { ный }\end{array}$} & 4 & Щегловский & $\begin{array}{l}\text { Провалы в форме } \\
\text { конических, чаше- } \\
\text { образных колодцев, }\end{array}$ & 8,83 & Более 5 \\
\hline & 5 & $\begin{array}{c}\text { Низовья рр Сежи- } \\
\text { Бежки }\end{array}$ & Воронки & 74,11 & 2 \\
\hline & 6 & $\begin{array}{l}\text { Низовья рек Бежки- } \\
\text { Тулицы-Волоть }\end{array}$ & $\begin{array}{c}\text { Воронки, провалы, } \\
\text { карстовые озера }\end{array}$ & 122,5 & 3 \\
\hline & 7 & $\begin{array}{c}\text { Низовья рек Волоть- } \\
\text { Упка }\end{array}$ & Воронки & 42,77 & 1 \\
\hline & 8 & Остальная площадь & $\begin{array}{c}\text { Воронки, карстовые } \\
\text { озера }\end{array}$ & 465,3 & 1 \\
\hline \multirow[t]{2}{*}{$\begin{array}{l}\text { Скура- } \\
\text { товский }\end{array}$} & 9 & Ливенский & $\begin{array}{c}\text { Воронки, карстовые } \\
\text { озера, провалы }\end{array}$ & 102,8 & Более 5 \\
\hline & 10 & $\begin{array}{c}\text { Яснополянско- } \\
\text { Коптевский }\end{array}$ & Воронки, провалы & 256,1 & 1 \\
\hline
\end{tabular}

Карта-схема зонирования территории МО г. Тула с учетом указанной таблицы представлена на рисунке.

Перспективы дальнейших исследований по данной тематике заключаются в прогнозировании и создании комплексных схем зонирования территории г. Тула с учетом таких опасных экзогенных процессов, как суффозия, подтопление, оврагообразование, речная эрозия и прочее. 


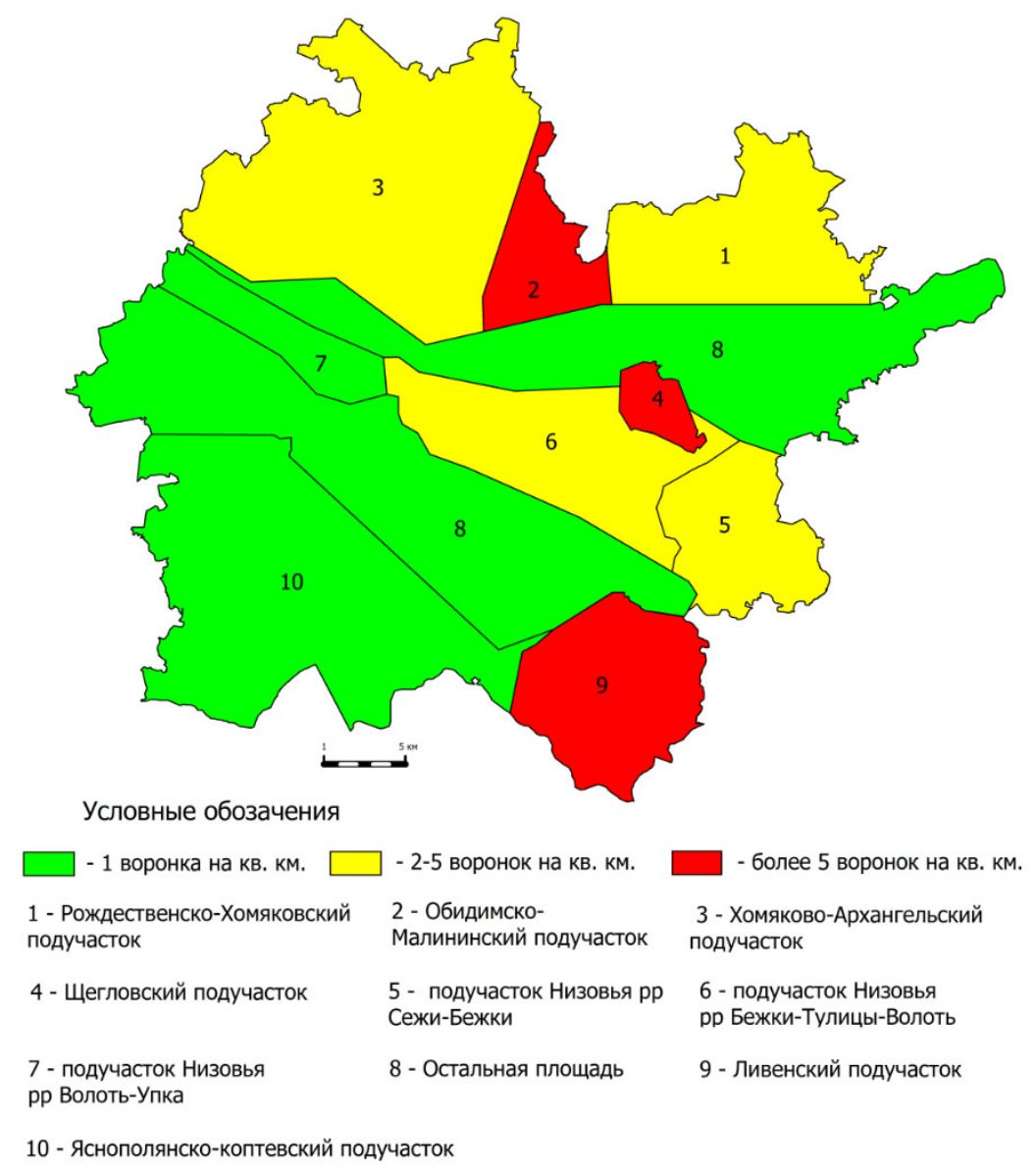

\section{Карта-схема зонирования территории МО г. Тулы с учетом карстовых процессов}

\section{БИБЛИОГРАФИЧЕСКИЙ СПИСОК}

1. ГОСТ Р 22.1.06-99 "Безопасность в чрезвычайных ситуациях. Мониторинг и прогнозирование опасных геологических явлений и процессов. Общие требования" (принят постановлением Госстандарта РФ от 24 мая 1999 г. N 177).

2. Басова И.А., Чекулаев В.В.. Оценка состояния и качества земель г. Тула с учетом природных геологических факторов. Коллективная монография «Избранные проблемы и перспективные вопросы землеустройства, кадастров и развития территорий - 2017: коллективная монография / кол. авторов; под общ. ред. А.П.Сизова. - Москва: РУСАЙНС, 2018. С 124-130.

3. Геоэкология хозяйственного комплекса Тулы и области / Э.М.Соколов, А.В. Дмитраков, А.Ф.Симанкин, В.В.Решетов.- Тула:ТулГУ, 2000.- с.110.

4. Дымов В.С., Сычев А.И., Гуркин В.В. Недра Тульской области. ОАО Подмосковное геологическое предприятие «Тула-Недра», Изд.-пол. Предприятие «Гриф и Ко», Тула 1999. 248c., ил.

5. Курбаниязова И.И., Покладенко С.И., Молчанова Л.А. Информационный бюллетень о состоянии геологической среды на территории Тульской области за 2006 г. Тула, 2007.

6. Курбаниязова И.И., Покладенко С.И. Информационный бюллетень о состоянии геологической среды на территории Тульской области за 2008 г., Тула, 2009.

7. Попов И.В. Инженерная геология СССР, т.1, М.,1978г.

8. Попов И.В. Инженерная геология СССР. Ч.ІІ.Европейская - часть - СССР, Учебное пособие - М., Изд-во - Моск. ун-та, 1965 г., 477с. 
9. Севостьянов Ю.А. Исследование карста в южном крыле подмосковного бассейна применительно к практике разведки и эксплуатации угольных месторождений: дисс. на соискание ученой степени доктора технических наук /Тул.политехнический институт, Т.-1971.

10. Сизов А.П. Оценка качества и мониторинг земель сверхкрупного города (на примере Москвы). М. : Изд-во МИИГАиК, 2012. — 239 с.

11. Сизов А.П., Клюев Н.Н. Оценка экологического состояния земельных участков на особо охраняемых природных территориях города // Геогр. и прир. ресурсы. - 2004. - № 1. C. $36-44$.

12. Региональный доклад «О состоянии и использовании земель в Тульской области в 2018 году» (подготовлен Федеральной службой государственной регистрации, кадастра и картографии по Тульской области) - от 01.01.2019.

13. Чекишев А.Г. Карст Русской равнины. Издательство «Наука». М., 1978, с. 194.

14. Чекулаев В.В., Цибулькина К. А. Изученность распространения экзогенных геологических процессов на территории Тульской области // Сборник научных трудов 3-ей Международной научно-технической интернет конференции «Кадастр недвижимости и мониторинг природных ресурсов : сб. научн. тр. / под общей ред. д-ра техн. наук, проф. И.А.Басовой. Тула: Изд-во ТулГУ, 2018. - с. 238-292 (дата обращения 15.11.2019).

15. Фондовые материалы. Отчет по изучению экзогенных геологических процессов Тульской области. Министерство геологии СССР. Производственное геологическое объединение «Центргеология». Подмосковная геологоразведочная экспедиция». Тула. 1987.

(C) И. А. Басова, В. В. Чекулаев, 2021 